\title{
DAMPAK NON TARIFF MEASURES (NTMS) TERHADAP EKSPOR UDANG INDONESIA
}

\section{The Impact of Non Tariff Measures (NTMs) on Indonesia's Shrimp Export}

\author{
Septika Tri Ardiyanti, Ayu Sinta Saputri \\ Pusat Pengkajian Perdagangan Luar Negeri, Badan Pengkajian dan Pengembangan Perdagangan, \\ Kementerian Perdagangan, JI. M.I Ridwan Rais 5, Jakarta, 10110, Indonesia \\ email: sept tika@yahoo.com
}

Naskah diterima: 01/08/2017; Naskah direvisi: 14/03/2018; Disetujui diterbitkan: 11/04/2018 Dipublikasikan online: 31/07/2018

\begin{abstract}
Abstrak
Penelitian ini bertujuan untuk menganalisis dampak kebijakan non tarif terhadap ekspor udang dan olahannya dari Indonesia. Untuk mengetahui dampak NTM terhadap ekspor, penelitian ini menggunakan gravity model dengan panel data. Variabel yang digunakan antara lain volume ekspor udang dan olahannya, PDB negara tujuan ekspor, nilai tukar riil, jarak ekonomi, tarif bea masuk dan variabel NTM berupa SPS dan TBT. Hasil menunjukkan bahwa NTM memiliki pengaruh negatif terhadap ekspor udang dan olahan udang nasional. Pengenaan TBT di negara tujuan ekspor memiliki dampak negatif yang lebih besar dibandingkan dengan SPS. Volume ekspor udang dan olahan ke negara mitra yang menerapkan TBT 30,2\% lebih rendah dibandingkan dengan negara yang tidak menerapkan TBT, sementara ekspor ke negara dengan SPS 21,3\% lebih rendah dibandingkan dengan negara yang tidak menerapkan SPS. Hal tersebut menunjukkan bahwa Indonesia belum mampu untuk memenuhi standar dan persyaratan impor yang diterapkan di negara tujuan ekspor. Dengan demikian, pemerintah diharapkan dapat memberikan bantuan bagi para eksportir udang dengan memberikan bantuan informasi pasar serta regulasi yang berlaku di negara tujuan ekspor. Selain itu, pemerintah juga perlu untuk memberikan dukungan sehingga eksportir dapat memenuhi standar dan persyaratan yang berlaku di negara tujuan ekspor.
\end{abstract}

Kata kunci: Ekspor Udang, Gravity Model, Non Tariff Measures (NTMs)

\begin{abstract}
This study aims to analyze the impact of non-tariff policy on shrimp and processed shrimp in Indonesia. To analyze the impact of NTM on Indonesia's shrimp export, this study uses gravity model with panel data. Variables used are export volume of Indonesia's shrimp and processed shrimp, GDP of export destination countries, real exchange rate, economic distance, import duty and NTM variables (SPS and TBT). This study shows that NTM has negative impact on shrimp exports. The imposition of TBT in export destination countries has a greater negative impact on shrimp export $c$ than SPS. The shrimp export volume to the partner countries appliying TBT is 30,2\% lower than countries that not applying TBT, while exports to cpuntries imposing SPs is $21,3 \%$ lower than countries without SPS. This fact indicates that Indonesia's exporters has not been able to meet standards and requirements applied by export destination countries. Therefore, the government is expected to provide assistance to the exporters by providing market information, regulation and requirements in export destination country. In addition, the government also needs to provide support so that exporters could meet the standards and requirements applied by export destination countries.
\end{abstract}

Keywords: Shrimp's export, Gravity Model, Non Tariff Measures (NTMs)

JEL Classification: F10, F13, F14 


\section{PENDAHULUAN}

Sebagai negara maritim dan kepulauan, sektor perikanan tentu memiliki peran strategis sebagai sektor utama pilar perekonomian nasional dan menjadi sumber peningkatan devisa negara dari sisi ekspor (Kristriana, 2015). Dengan demikian, sektor perikanan merupakan salah satu sektor prospektif Indonesia untuk terus ditingkatkan ekspornya, baik dari volume maupun dari peningkatan nilai tambah ekspornya.

Salah satu komoditas sektor perikanan yang menjadi kontributor ekspor terbesar Indonesia adalah Udang dan produk olahan udang. Ekspor udang di tahun 2016 mencapai USD 1,7 Milyar, dan menyumbang sebesar $43,3 \%$ dari total ekspor ikan dan produk olahan ikan di tahun 2016. Ekspor udang di tahun 2016 tersebut terdiri dari ekspor udang beku dengan nilai ekspor sebesar USD 1,3 Milyar, serta udang kemasan dan udang lainnya yang nilai ekspornya masingmasing mencapai USD 354,4 Juta dan USD 31,2 Juta (BPS, 2017). Beberapa negara tujuan ekspor udang dan produk olahan udang Indonesia antara lain Amerika Serikat, Jepang dan beberapa negara di Uni Eropa seperti Inggris, Belanda dan Jerman serta negara di Asia seperti Vietnam dan Republik Rakyat Tiongkok (RRT) (Trademap, 2017).

Di pasar dunia, permintaan udang mencapai USD 25,7 miliar pada tahun 2016, meningkat cukup signifikan sebesar $17,1 \%$ dibandingkan dengan permintaan pada tahun 2016 (Trademap, 2017). Permintaan dunia akan udang tersebut lebih tinggi dari permintaan produk perikanan lainnya seperti ikan beku, ikan fillet, ikan segar, serta produk perikanan lainnya. Indonesia termasuk sebagai eksportir terbesar dunia karena mampu menyuplai $5,7 \%$ permintaan udang dunia pada tahun 2016 (Trademap, 2017). Meskipun demikian, posisi Indonesia masih lebih rendah dari negara-negara lain seperti India, Ekuador, Kanada, Vietnam, dan RRT (Trademap, 2017).

Tingginya permintaan pasar akan produk udang dari negara pengimpor tentu menjadi peluang emas bagi Indonesia. Namun demikian, tingginya permintaan pasar tersebut bukan berarti ekspor udang Indonesia tidak mengalami hambatan. Semakin meningkatnya isu non tarif seperti Sanitary and phytosanitary (SPS) dan Technical barriers to trade (TBT) yang banyak di terapkan di negara 
pengimpor seperti Amerika Serikat, Jepang dan negara Uni Eropa menjadi tantangan bagi ekspor udang Indonesia. Pemberlakuan non tarif tersebut merupakan bentuk kebijakan yang diterapkan sebagai pengganti kebijakan tarif yang pemberlakuannya mulai menurun karena penetapan tingkat tarif di berbagai negara yang semakin dibatasi (Ariyani, 2016). Terdapat beberapa contoh kasus ekspor berupa potensi penolakan ekspor udang yang disebabkan negara pengimpor telah mensyaratkan standar kesehatan berupa sertifikasi bebas virus tertentu seperti yang telah diterapkan di negara kawasan Amerika di tahun 2016 (Media Indonesia, 2016).

Meskipun demikian, dampak Non Tariff Measures (NTMs) terhadap ekspor tidak konklusif. Menurut model Melitz (2003) dalam Shepotylo (2016), peningkatan yang terjadi pada fixed cost produksi akan membuat daya saing perusahaan dalam negeri yang kurang produktif semakin menurun, sehingga mendorong masuknya importir. Dengan kata lain, semakin tinggi standar yang diterapkan terhadap suatu produk di suatu negara, yang menyebabkan naiknya biaya tetap produksi di negara tersebut, akan memberikan dampak positif extensive margin perdagangan bagi eksportir (Shepotylo, 2016). Sementara itu, tingginya standar tersebut dapat meningkatkan fixed cost untuk ekspor dan menyebabkan keluarnya eksportir yang tidak produktif dari pasar ekspor, sehingga mengurangi extensive margin perdagangan (Shepotylo, 2016). Oleh karena itu, sulit untuk mengatakan secara apriori apakah NTM memiliki efek positif atau negatif terhadap ekspor.

Beberapa penelitian telah dilakukan untuk mengidentifikasi dampak NTM terhadap kinerja ekspor suatu negara. Pada 2005, Fontagne, et al. melakukan estimasi dampak kebijakan NTMs (SPS dan TBT) terhadap kinerja ekspor negara anggota OECD (Organization of Economic Cooperation and Development), negara berkembang (Developing Country) dan negara miskin (Least Developed Countries). Studi tersebut menunjukkan bahwa dampak NTMs bervariasi diantara kelompok negara-negara tersebut. SPS dan TBT memiliki dampak negatif dan signifikan pada negara-negara berkembang, dampak positif dan signifikan pada negara LDCs, sedangkan untuk negara-negara OECD tidak memiliki dampak signifikan. Bratt 
(2017) juga mengkaji dampak bilateral NTMs dari 85 negara. Dengan menggunakan metode gravity model, hasil analisis menunjukkan bahwa NTM yang diterapkan oleh negara maju memiliki dampak negatif terhadap ekspor negara berkembang. Selain itu, hasil analisis tersebut menyimpulkan bahwa NTM yang diterapkan oleh negara maju memiliki dampak yang lebih besar dibandingkan dengan NTM yang diterapkan oleh negara berkembang.

Untuk kasus Indonesia, Kristriana (2015) menggunakan pendekatan gravity model untuk mengetahui dampak NTMs terhadap ekspor ikan tuna Indonesia ke negara tujuan ekspor utama. Variabel independen yang digunakan dalam kajian tersebut antara lain GDP per kapita negara importir, poulasi negara importir, jarak ekonomi antara kedua negara, NTMs negara importir dan nilai tukar riil, sementara ekpor ikan tuna Indonesia menjadi variabel dependent dalam model tersebut. Kajian tersebut menunjukkan bahwa implementasi NTMs justru berpengaruh positif dan signifikan bagi kinerja ekspor ikan tuna Indonesia. Margaretha (2012) juga menganalisis dampak SPS yang diterapkan oleh Uni Eropa terhadap ekspor udang
Indonesia dengan menggunakan model gravity. Hasil analisis tersebut menunjukkan bahwa SPS dapat menurunkan nilai ekspor udang Indonesia karena kebijakan tersebut dinilai bersifat menghambat perdagangan udang.

Dahar (2014) juga melakukan studi untuk mengidentifikasi dampak kebijakan NTM terhadap kinerja ekspor produk hortikultura Indonesia di negara ASEAN +3 (ASEAN + Jepang, Cina, dan Korea Selatan). Variabel independent yang digunakan dalam model tersebut antara lain: GDP per kapita negara importir, populasi negara pengimpor, jarak ekonomi dan kebijakan NTMs (SPS dan TBT). Studi tersebut menunjukkan bahwa kebijakan non tariff berupa SPS dan TBT berpengaruh negatif dan signifikan terhadap ekspor produk hortikultura Indonesia. Dengan demikian, hingga saat ini belum terdapat hubungan yang jelas terkait dampak NTMs terhadap kinerja ekspor suatu negara. Hal tersebut terlihat dari beberapa penelitian yang menyatakan bahwa NTMs memberikan dampak positif dan signifikan, namun terdapat penelitian lain yang menyatakan bahwa NTMs justru memiliki dampak negatif dan signifikan terhadap kinerja ekspor serta 
bahkan terdapat penelitian yang menyatakan bahwa NTMs justru tidak berpengaruh positif terhadap kinerja perdagangan luar negeri suatu negara.

Fridhowati (2013) mengkaji dampak NTM yang diterapkan oleh negara-negara ASEAN untuk melindungi produsen dalam negeri (core NTM) dan NTM untuk melindungi konsumen dalam negeri (non core NTM) terhadap ekspor elektronik Indonesia dengan menggunakan pendekatan coverage ratio dan gravity model. Hasil empiris menunjukkan bahwa core NTM memiliki dampak negatif terhadap ekspor elektronik Indonesia ke ASEAN, sebaliknya peningkatan non core NTM justru akan meningkatkan ekspor sektor tersebut. Sementara itu, Hasil analisis Sari et al., (2018) mengenai dampak NTM terhadap ekspor CPO Indonesia menunjukkan bahwa dampak NTM secara keseluruhan terhadap ekspor CPO ke negara-negara tujuan ekspor utama Indonesia tidak signifikan. Namun, bila dilihat dampaknya berdasarkan jenis NTM, yaitu SPS, TBT dan trade remedy, hasil analisis menunjukkan bahwa hanya TBT yang secara signifikan menghambat ekspor CPO Indonesia.
Oleh karena itu, dalam rangka menghadapi kebijakan-kebijakan non tarif yang telah banyak ditetapkan oleh negara pengimpor pada komoditi udang, maka kajian ini bertujuan untuk menganalisis dampak kebijakan non tarif terhadap ekspor udang dan udang olahan Indonesia. Kajian ini juga diharapkan dapat memberikan insight terkait implikasi kebijakan non tarif yang diterapkan oleh negara pengimpor menjadi hambatan atau justru menjadi peluang bagi ekspor udang Indonesia.

\section{METODE}

Untuk mengetahui dampak NTM terhadap kinerja ekspor udang Indonesia, studi ini menggunakan pendekatan gravity model. Gravity model merupakan salah satu alat yang paling banyak digunakan untuk menggambarkan aliran perdagangan luar negeri suatu negara dan merupakan alat yang cukup populer untuk digunakan (Xiong, 2012). Secara teoritis, gravity model mengindikasikan bahwa perdagangan antar negara berhubungan positif terhadap PDB negara tujuan ekspor dan berhubungan negatif dengan trade cost dan trade barriers dan antar negara. Trade cost dan trade barries perdagangan antar 
negara dapat meliputi jarak antar

Secara umum, gravity model negara, tarif bea masuk, NTM yang perdagangan bilateral didefinisikan diterapkan oleh negara tujuan dan fixed trade cost lainnya (Xiong, 2012). sebagai berikut (Sheldon, Mishra, \& Thompson, 2013) dalam (Kahfi, 2016):

$X^{i j}=\beta_{0}\left(G D P_{i}\right)^{\beta_{1}}\left(G D P_{j}\right)^{\beta_{z}}\left(D_{i s t^{i j}}\right)^{\beta_{a}}\left(A^{i j}\right)^{\beta_{4}} u^{i j}$

dimana:

$X^{i j}$ merupakan nilai ekspor negara $i$ ke

Spesifikasi Model

negara $j, G D P_{j}$ merupakanPDB negara

Mengacu pada beberapa

$j$, Dist ${ }^{i j}$ merupakan jarak antara negara penelitian terdahulu, maka model ekonometrik yang digunakan untuk $i$ dan negara $j$ dan $A^{i j}$ merupakan vektor faktor determinaan ekspor negara i ke negara j, termasuk di dalamnya trade barriers dan trade cost antara negara $i$ dan negara $j$. mengetahui dampak NTMs terhadap kinerja ekspor produk perikanan dan kelautan Indonesia ke pasar Uni Eropa pada kajian ini didefinisikan sebagai berikut:

$\mathrm{X}_{\text {IDNit }}=\alpha_{1} \mathrm{GDP}_{\text {it }}+\alpha_{2} \mathrm{RER}_{\mathrm{IDNit}}+\alpha_{3}$ DistecoIDNit $+\alpha_{4} \mathrm{BM}_{\mathrm{it}}, \alpha_{5} \mathrm{dSPS}$ it, $\alpha_{6} \mathrm{dTBT}$ it

Hipotesis: $\alpha_{1, \alpha_{2}>0}>\alpha_{3}, \alpha_{4}<0 ; \alpha_{5}, \alpha_{6}=+/-$

Dimana:

XIDNit (Volume ekspor udang dan udang pada periode $t$, dimana $D=1$ : produk olahan udang Indonesia ke negara tujuan ekspor $i$ pada periode $\mathrm{t}$ ); Variabel yang merefleksikan adanya

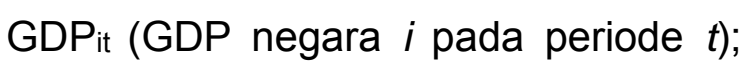
ERIDNit (Nilai tukar riil Indonesia dengan negara tujuan ekspor $i$ pada periode $t$ ); DistecoIDNit (Jarak ekonomi negara $i$ dan Indonesia); BMit (Rata-rata tarif bea masuk udang dan olahan udang di negara tujuan ekspor $i$ pada periode $t$ ); SPS it (Dummy SPS negara pengimpor $i$ terhadap produk udang dan olahan SPS dan $D=0$ : Tidak terdapat SPS);

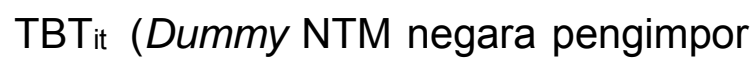
$i$ terhadap produk udang dan olahan pada periode $t$, dimana $D=1$ : Variabel yang merefleksikan adanya TBT dan $\mathrm{D}=0$ : Tidak terdapat terdapat TBT).

Nilai tukar riil Indonesia Rupiah terhadap mata uang negara tujuan ekspor $i$ dihitung berdasarkan persamaan berikut: 
$R E R=N E R \times \frac{C P I^{i}}{C P I^{I D N}}$

dimana NER merupakan nilai tukar nominal IDR terhadap mata uang negara tujuan ekspor $i$, CPli merupakan Consumer Price Index (Indeks Harga Konsumen) di negara $i$ dan CPIIDN merupakan Consumer Price Index (Indeks Harga Konsumen) Indonesia. CPI yang digunakan adalah berdasarkan indeks 2010 $=100$.

Menurut Putri (2014), jarak ekonomi antar negara dihitung berdasarkan persamaan berikut:

Disteco $_{I D N i t}=\frac{\text { JarakGeografisantaraIndonesiadanNegarai }}{\text { GDPNegarai }}$

Data yang digunakan dalam kajian ini merupakan data sekunder yang diperoleh dari berbagai sumber antara lain Badan Pusat Statistik (BPS), ITC
Trademap, International Monetary Fund (IMF), World Bank dan UN Comtrade. Secara detail, data dan sumber data disajikan pada Tabel 1.

\section{Tabel 1. Jenis dan Sumber data}

\section{Jenis Data}

Ekspor udang dan olahan udang Indonesia Nilai tukar riil (IDR/Mata Uang Negara Tujuan Ekspor i) GDP negara tujuan eskpor i Jarak antara negara tujuan ekspor i dengan Indonesia Populasi negara tujuan eskpor i Rata-rata tarif Bea Masuk negara i NTM (SPS dan TBT)

\section{Sumber Data}

Badan Pusat Statistik

Bank Indonesia dan World Bank International Monetary Fund CEPII International Monetary Fund World Trade Organization UN Comtrade

\section{Ruang Lingkup}

Kebijakan Non Tariff Measure (NTM) didefinisikan sebagai kebijakan perdagangan internasional selain tarif yang berpotensi menimbulkan dampak ekonomi pada perdagangan internasional barang, perubahan kuantitas yang diperdagangkan serta harga barang yang diperdagangkan dan atau keduanya (UNCTAD, 2012).
Hambatan NTM tersebut pada dasarnya merupakan bentuk proteksi suatu negara pada prodiusen domestik dalam benbagai bentuk kebijakan seperti pengendalian impor dan berbagai persyaratan dan standar teknis dengan tujuan untuk melindungi produsen dalam negeri dalam menghadapi persaingan dengan barang-barang impor serta melindungi 
konsumen dalam negeri (Ariyani, 2016). Dengan demikian, NTM memiliki definisi yang cukup luas sehingga perlu dilakukan klasifiksi untuk dapat membedakan antara kebijakan NTM yang satu dengan yang lainnya. NTM kemudian dikategorikan berdasarkan ruang lingkup dan ukuran teknisnya (UNCTAD, 2013).

SPS dan TBT merupakan kebijakan NTM yang paling banyak diterapkan di negara maju yang juga sekaligus menjadi negara tujuan ekspor utama udang Indonesia dengan nilai coverage ratio masing-masing di atas
0,1 dan 0,6 (Gambar 1). Dua chapter NTM tersebut, juga merupakan kebijakan NTM yang paling banyak diterapkan untuk prduk perikanan salah satunya udang (Kristriana, 2015). Pada studi ini, kebijakan NTM yang akan dianalisis lebih lanjut dampaknya terhadap ekspor udang Indonesia adalah berfokus pada SPS dan TBT yang merupakan bagian dari technical measure. Sementara produk udang yang dikaji adalah udang dan produk olahan yang masuk ke dalam pos tarif 030613, 030623, 160520 dan 160530.

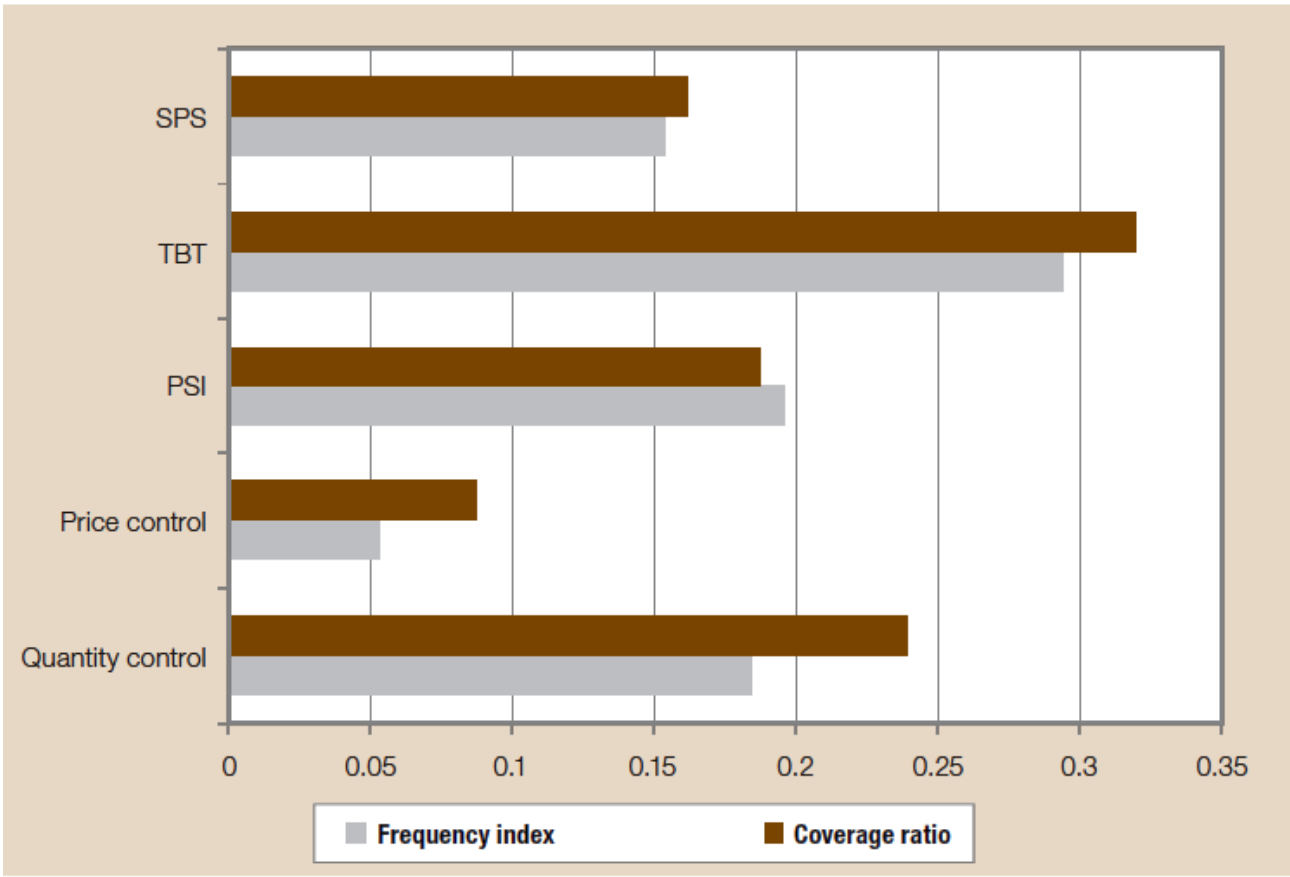

Gambar 1. Indeks Frekuensi dan Coverage Ratio NTMs di Semua Negara Sumber: UNCTAD, 2013 
HASIL DAN PEMBAHASAN

Kinerja Ekspor Udang Indonesia

Sebagai negara maritim, Indonesia memiliki potensi yang luar biasa di sektor perikanan. Namun demikian, potensi tersebut belum dimanfaatkan secara optimal, hal tersebut terlihat dari masih rendahnya kontribusi sektor perikanan terhadap
PDB Indonesia yang masih berada di kisaran 2\%. Namun demikian, pada triwulan I 2017, kontribusi sektor perikanan terhadap PDB mengalami sedikit peningkatan dibandingkan dengan periode yang sama tahun sebelumnya dari $2,6 \%$ menjadi $2,62 \%$ (Tabel 2).

Tabel 2. Distribusi PDB Sektor Pertanian, Kehutanan dan Perikanan

\begin{tabular}{llrrrr}
\hline & & \multicolumn{4}{c}{ Distribusi PDB } \\
\cline { 3 - 6 } No. & PDB Lapangan Usaha (Seri 2010) & $\mathbf{2 0 1 4}$ & $\mathbf{2 0 1 5}$ & $\mathbf{2 0 1 6}$ & $\mathbf{2 0 1 7}$ \\
\hline \multirow{2}{*}{$\begin{array}{l}\text { Pertanian, Kehutanan, dan Perikanan } \\
\text { Pertanian, Peternakan, Perburuan dan }\end{array}$} & 13.34 & 13.49 & 13.45 & 13.59 \\
$\quad$ Jasa Pertanian & 10.31 & 10.27 & 10.21 & 10.35 \\
$\quad$ a. Tanaman Pangan & 3.25 & 3.45 & 3.42 & 4.06 \\
$\quad$ b. Tanaman Hortikultura & 1.52 & 1.51 & 1.51 & 1.40 \\
$\quad$ C. Tanaman Perkebunan & 3.77 & 3.51 & 3.46 & 3.07 \\
$\quad$ d. Peternakan & 1.58 & 1.60 & 1.62 & 1.61 \\
$\quad$ e. Jasa Pertanian dan Perburuan & 0.19 & 0.20 & 0.20 & 0.20 \\
2 & Kehutanan dan Penebangan Kayu & 0.71 & 0.72 & 0.69 & 0.63 \\
3 & Perikanan & 2.32 & 2.51 & 2.56 & 2.62 \\
\hline
\end{tabular}

Sumber: BPS, (2017a)

Di sisi perdangan luar negeri, ekspor ikan dan olahan perikanan Indoensia menunjukkan tren pertumbuhan yang positif sebesar $0,8 \%$ per tahun selama lima tahun terakhir, 2012-2016, meskipun kontribusi ekspor ikan dan olahan perikanan terhadap ekspor non migas di tahun 2016 baru mencapai 2,9\%. Pangsa ekspor ikan dan olahan perikanan selama lima tahun terakhir masih berada di sekitar 2\%. Ekspor ikan dan olahan perikanan di tahun 2016 mencapai USD 3,9 Milyar di tahun 2016, meningkat cukup signifikan sebesar 7,2\% YoY. Selama periode Januari-Maret 2017, ekspor ikan dan olahan perikanan mencapai USD 899,0 Juta atau naik 0,43\% dibandingkan dengan periode yang sama tahun sebelumnya (Gambar 2). 


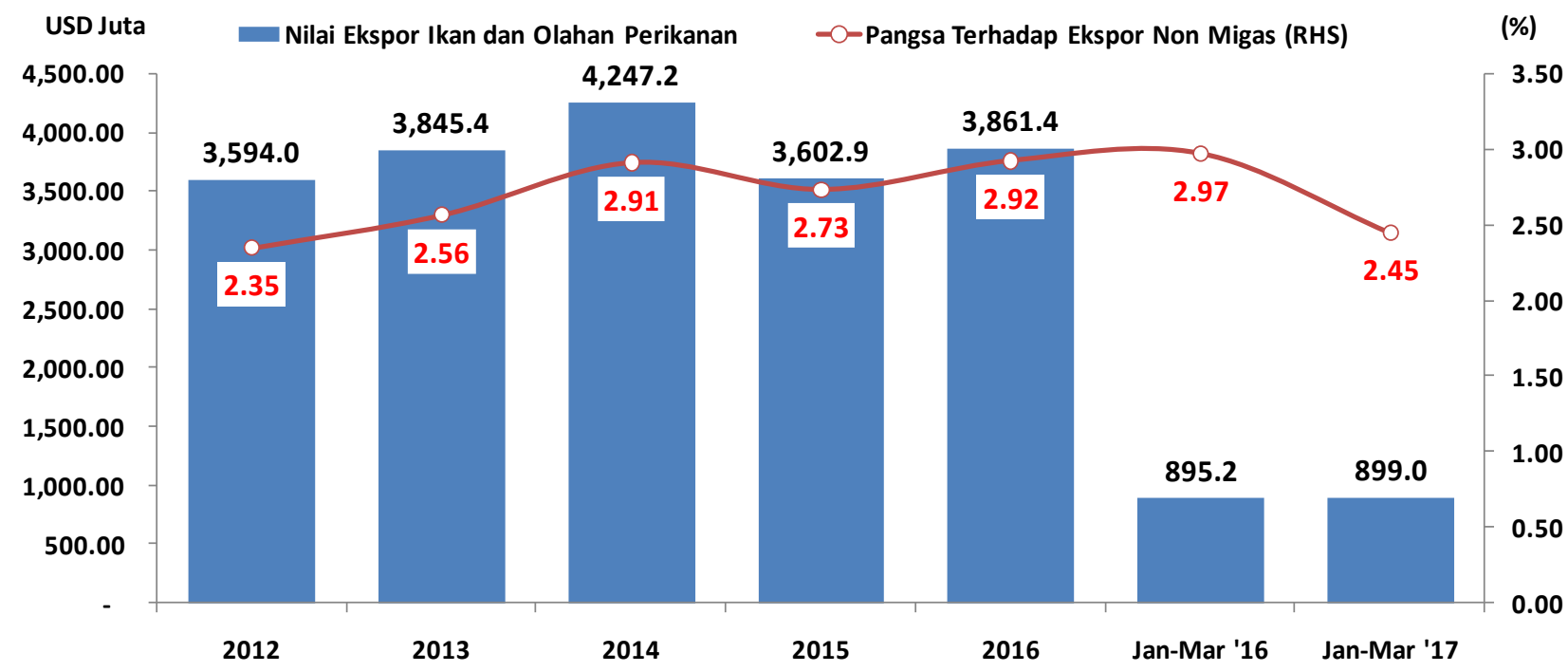

Gambar 2. Perkembangan Ekspor Ikan dan Olahan Perikanan Indonesia, 2012-2017 (Jan-Mar)

Sumber: BPS, 2017c (diolah)

Udang dan olahan udang merupakan kontributor utama ekspor ikan dan olahan perikanan dengan pangsa ekspor mencapai $43,4 \%$ terhadap total ekspor ikan dan olahan perikanan Indonesia di tahun 2016. Belahan ikan (fillet) dan ikan kemasan/olahan, sotong dan cumicumi serta kepiting kemasan merupakan produk yang masuk dalam lima besar kelompok produk kontributor ekspor sektor ikan dan olahan perikanan. Keempat produk tersebut memiliki pangsa masing-masing sebesar $11,2 \%, 8,5 \%, 7,2 \%$ dan $6,7 \%$. Dengan demikian, kelima produk tersebut telah memiliki pangsa sebesar $76,9 \%$ dari total eskpor ikan dan olahan perikanan Indonesia.
Ekspor udang dan udang olahan Indonesia yang merupakan kontributor utama, mencapai USD 1,7 Milyar di tahun 2016, naik $6,4 \%$ dibandingkan tahun sebelumnya. Selama periode 2012 sampai dengan 2016, ekspor udang dan olahan udang Indonesia terus memiliki tren pertumbuhan positif dengan tumbuh sebesar $6,2 \%$ per tahun, tumbuh lebih tinggi dibandingkan tren pertumbuhan ekspor ikan dan olahan perikanan Indonesia secara agregat. Selama Januari-Maret 2017, ekspor udang dan olahan udang mencapai USD 389,4 Juta, naik dibandingkan periode Januari-Maret 2016 yang hanya mencapai USD 382,4 Juta (1,8\% YoY) (Tabel 3 ). 
Tabel 3. Kinerja Ekspor Ikan dan Olahan Perikanan Menurut Kelompok

\begin{tabular}{|c|c|c|c|c|c|c|c|}
\hline \multirow[b]{2}{*}{ No. } & \multirow{2}{*}{ Uraian } & \multicolumn{3}{|c|}{ Nilai (USD Juta) } & \multirow{2}{*}{$\begin{array}{l}\text { Growth. } \\
\text { (\%) '17/16 }\end{array}$} & \multirow{2}{*}{$\begin{array}{l}\text { Trend (\%) } \\
\text { '12-16 }\end{array}$} & \multirow{2}{*}{$\begin{array}{c}\text { Share } \\
(\%) \\
2016\end{array}$} \\
\hline & & 2016 & $\begin{array}{c}\text { Jan-Mar } \\
116\end{array}$ & $\begin{array}{c}\text { Jan-Mar } \\
\cdot 17\end{array}$ & & & \\
\hline & $\begin{array}{l}\text { Ekspor Ikan dan Olahan } \\
\text { Perikanan }\end{array}$ & $3,861.40$ & 895.22 & 899.04 & 0.43 & 0.79 & 100.00 \\
\hline 1 & Udang dan Olahan Udang & $1,676.35$ & 382.37 & 389.39 & 1.83 & 6.24 & 43.41 \\
\hline 2 & Belahan Ikan (fillet) & 431.71 & 99.84 & 89.67 & -10.19 & 1.56 & 11.18 \\
\hline 3 & Ikan kemasan/olahan & 327.88 & 77.95 & 77.59 & - 0.47 & -6.50 & 8.49 \\
\hline 4 & Sotong dan cumi-cumi & 277.26 & 58.38 & 54.99 & -5.80 & 30.39 & 7.18 \\
\hline 5 & kepiting kemasan/olahan & 256.79 & 65.41 & 57.29 & -12.41 & 13.94 & 6.65 \\
\hline 6 & $\begin{array}{l}\text { Kerapu, ikan laut, ikan tawar } \\
\text { beku }\end{array}$ & 231.77 & 51.97 & 45.95 & -11.59 & -0.88 & 6.00 \\
\hline 7 & $\begin{array}{l}\text { Kerapu, ikan laut, ikan tawar } \\
\text { segar/dingin }\end{array}$ & 87.80 & 22.07 & 18.93 & -14.21 & 13.55 & 2.27 \\
\hline 8 & Lobsters & 81.88 & 20.90 & 15.92 & -23.83 & 6.48 & 2.12 \\
\hline 9 & Ikan hidup/hias & 70.01 & 18.97 & 19.76 & 4.14 & 2.43 & 1.81 \\
\hline 10 & Ikan kering (diasinkan) & 60.95 & 11.70 & 14.92 & 27.48 & -15.99 & 1.58 \\
\hline 11 & Tuna beku & 53.07 & 9.35 & 13.58 & 45.26 & -21.95 & 1.37 \\
\hline 12 & Gurita & 51.61 & 15.71 & 15.97 & 1.66 & -2.77 & 1.34 \\
\hline 13 & Crabs (kepiting) & 43.52 & 13.65 & 29.65 & 117.13 & -29.15 & 1.13 \\
\hline 14 & Ikan beku lainnya & 42.27 & 8.80 & 7.36 & -16.43 & -10.26 & 1.09 \\
\hline \multirow[t]{2}{*}{15} & Skipjack/cakalang beku & 41.84 & 7.08 & 20.61 & 191.18 & -20.79 & 1.08 \\
\hline & Lainnya & 126.67 & 31.07 & 27.48 & -11.55 & -16.25 & 3.28 \\
\hline
\end{tabular}

Sumber: BPS, 2017b (diolah)

Ekspor udang Indonesia secara umum dapat dibagi ke dalam tiga kelompok produk antara lain: udang beku, udang kemasan/olahan serta kelompok produk yang termasuk ke dalam jenis udang lainnya. Ekspor udang dan olahan udang di tahun 2016 didominasi oleh ekspor udang beku dengan pangsa sebesar $78,3 \%$ dari total ekspor udang dan udang olahan. Pangsa udang beku tersebut, mengalami peningkatan jika dibandingkan dengan pangsa di tahun 2015 yang mencapai $77,4 \%$. Sementara itu, ekspor udang kemasan/olahan justru mengalami penurunan dari $21,9 \%$ di tahun 2015 menjadi $19,7 \%$ di tahun 2016 . Di kelompok udang jenis lainnya, terjadi peningkatan pangsa ekspor dari $0,7 \%$ di tahun 2015 menjadi $1,9 \%$ di tahun 2016 (Gambar 3). 

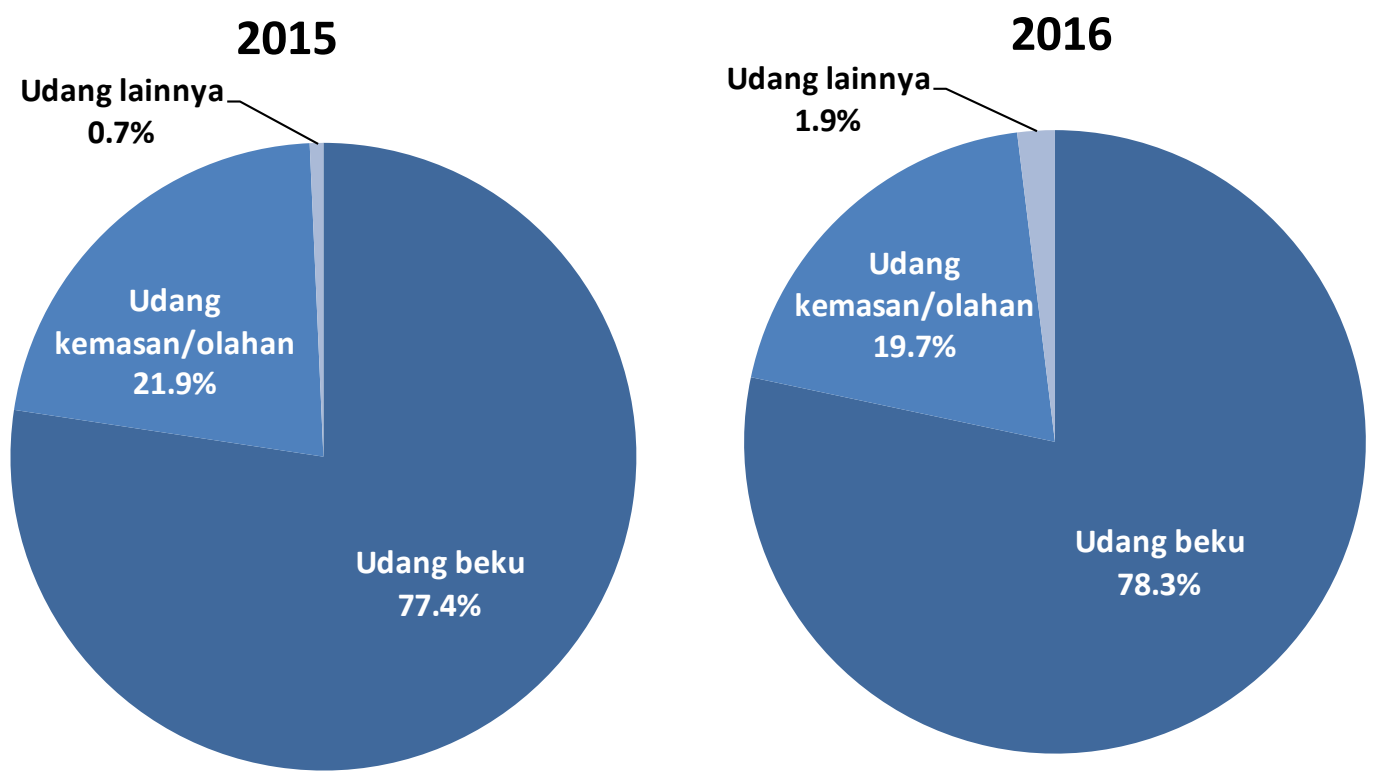

\section{Gambar 3. Struktur Ekspor Udang dan Olahan Udang}

Sumber: BPS, 2017 (diolah)

Nilai ekspor udang beku, Keseluruhan kelompok memiliki tren sebagai kontributor utama, mencapai pretumbuhan yang positif. Udang USD 1,3 Milyar di tahun 2016. Udang dalam kelompok lainnya merupakan dalam jenis kemasan dan kelompok udang lainnya masing-masing sebesar USD 330,7 Juta dan USD 86,8 Juta. kelompok udang yang memiliki tren pertumbuhan ekspor tertinggi sebesar $41,8 \%$ per tahun (Tabel 4).

Tabel 4. Nilai Ekspor Udang dan Olahan Udang Menurut Kelompok

\begin{tabular}{|c|c|c|c|c|c|c|c|}
\hline \multirow[b]{2}{*}{ Uraian } & \multicolumn{5}{|c|}{ Nilai (USD Juta) } & \multirow[b]{2}{*}{$\begin{array}{l}\text { Growth. } \\
\text { (\%) '17/16 }\end{array}$} & \multirow[b]{2}{*}{$\begin{array}{l}\text { Trend. } \\
\text { (\%) '12-16 }\end{array}$} \\
\hline & 2014 & 2015 & 2016 & $\begin{array}{c}\text { Jan-Mar } \\
' 16\end{array}$ & $\begin{array}{c}\text { Jan-Mar } \\
' 17\end{array}$ & & \\
\hline Udang \& Olahan Udang & $2,040.05$ & $1,574.86$ & $1,676.35$ & 382.37 & 389.39 & 1.83 & 6.24 \\
\hline Udang beku & $1,570.68$ & $1,218.69$ & $1,313.04$ & 292.89 & 301.11 & 2.81 & 6.22 \\
\hline Udang kemasan/olahan & 459.12 & 345.11 & 330.69 & 86.77 & 83.81 & 3.41 & 4.78 \\
\hline Udang lainnya & 10.24 & 11.06 & 32.63 & 2.71 & 4.46 & 64.42 & 41.82 \\
\hline
\end{tabular}

Sumber: BPS, 2017 (diolah)

Sementara itu, pasar ekspor udang dan olahan udang Indonesia sebagian besar ditujukan ke negara Amerika Serikat dan Jepang. Ekspor udang yang ditujukan ke kedua negara tersebut telah mencapai $83,2 \%$ dari total ekspor udang nasional. Di tahun 2016, total ekspor udang dan olahan 
udang Indonesia yang ditujukan ke Amerika Serikat mencapai USD 1,0 Milyar dengan pangsa $63,0 \%$ dari total ekspor udang nasional Indonesia. Sementara, ekspor ke Jepang mencapai USD 337,4 Juta berada di peringkat ke-2 negara tujuan ekspor dengan pangsa 20,13\%. Berdasarkan negara tujuan ekspor, ekspor udang dan olahan udang Indonesia masih terkonsentrasi pada beberapa pasar tujuan ekspor tertentu, terlihat dari kumulatif pangsa ekspor di 10 negara tujuan utama telah mencapai 95,87\%. Dengan berdasarkan pada data negara tujuan utama ekspor tersebut, dalam melakukan analisis dampak NTM terhadap kinerja ekspor, kajian ini akan berfokus pada 10 negara tujuan utama karena telah mencakup sebesar 95,87\% ekspor udang nasional (Tabel 5).

Tabel 5. Negara Tujuan Ekspor Udang dan Olahan Udang Indonesia

\begin{tabular}{|c|c|c|c|c|c|c|c|c|}
\hline \multirow[b]{2}{*}{ No } & \multirow[b]{2}{*}{ Negara } & \multicolumn{4}{|c|}{ Nilai (USD Juta) } & \multirow[b]{2}{*}{$\begin{array}{c}\text { Growth. } \\
\text { (\%) } \\
\cdot 17 / 16\end{array}$} & \multirow[b]{2}{*}{$\begin{array}{c}\text { Trend. } \\
(\%) \\
12-16\end{array}$} & \multirow[b]{2}{*}{$\begin{array}{c}\text { Pangsa } \\
(\%) \\
2016\end{array}$} \\
\hline & & 2015 & 2016 & $\begin{array}{c}\text { Jan- } \\
\text { Apr '16 }\end{array}$ & $\begin{array}{l}\text { Jan- } \\
\text { Apr } \\
\cdot 17\end{array}$ & & & \\
\hline & $\begin{array}{l}\text { Total Ekspor } \\
\text { Udang dan } \\
\text { Olahan Udang }\end{array}$ & $1,574.86$ & $1,676.30$ & 525.44 & 521.75 & -0.70 & 6.25 & 100.00 \\
\hline 1 & Amerika Serikat & 920.39 & $1,056.62$ & 324.97 & 333.36 & 2.58 & 12.97 & 63.03 \\
\hline 2 & Jepang & 357.03 & 337.40 & 104.61 & 112.96 & 7.98 & -6.57 & 20.13 \\
\hline 3 & Inggris & 54.73 & 48.70 & 19.47 & 11.53 & -40.78 & 13.59 & 2.91 \\
\hline 4 & Vietnam & 20.53 & 36.04 & 12.59 & 13.11 & 4.06 & -2.50 & 2.15 \\
\hline 5 & Belanda & 26.98 & 32.73 & 9.65 & 9.78 & 1.30 & -1.77 & 1.95 \\
\hline 6 & RRT & 61.90 & 25.70 & 12.05 & 5.76 & -52.21 & 34.05 & 1.53 \\
\hline 7 & Malaysia & 14.57 & 20.10 & 7.13 & 4.28 & -39.95 & 39.65 & 1.20 \\
\hline 8 & Jerman & 16.13 & 19.23 & 7.65 & 3.57 & -53.32 & 26.34 & 1.15 \\
\hline 9 & Puerto Rico & 7.00 & 15.91 & 0.80 & 3.67 & 359.38 & 20.08 & 0.95 \\
\hline \multirow[t]{2}{*}{10} & Kanada & 11.27 & 14.67 & 4.00 & 4.18 & 4.40 & 4.31 & 0.88 \\
\hline & Lainnya & 84.33 & 69.20 & 22.50 & 19.56 & -13.08 & -5.10 & 4.13 \\
\hline
\end{tabular}

Sumber: BPS, 2017 (diolah)

\section{Dampak NTMs Terhadap Ekspor}

\section{Udang Indonesia}

Metode yang digunakan untuk mengetahui dampak NTMs pada ekspor udang dan olahan udang Indonesia adalah dengan menggunakan pendekatan gravity model. Data yang digunakan adalah panel data yang merupakan kombinasi antara data cross section pada sembilan negara tujuan ekspor antara lain Amerika Serikat, Jepang, Inggris, 
Vietnam, Belanda, RRT, Malaysia, Indonesia sebesar 0,32\%. Hasil Jerman dan Kanada. Kesembilan negara tersebut telah menyumbangkan $91,8 \%$ dari total ekspor udang dan olahan udang Indonesia. Meskipun negara Puerto Rico termasuk ke dalam 10 besar negara tujuan ekspor, namun karena data NTM (SPS dan TBT) untuk negara tersebut tidak tersedia sehingga tidak dilakukan analisis lebih lanjut. Sementara untuk data time series yang digunakan antara rentang waktu 2005 sampai dengan 2015.

Hasil estimasi menunjukkan bahwa terdapat dua variabel yang signifikan mempengaruhi ekspor udang dan olahan udang yaitu variabel GDP negara tujuan ekspor dan jarak ekonomi antara Indonesia dengan negara tujuan ekspor yang ditunjukkan oleh nilai $p$-value masing-masing sebesar 0,07 dan 0,02 . Variabel GDP negara bernilai positif menunjukkan bahwa semakin besar semakin besar perekonomian negara tujuan ekspor, maka ekspor udang Indonesia akan semakin meningkat. Variabel GDP negara tujuan ekspor memiliki koefisien sebesar 0,32 menunjukkan bahwa peningkatan 1\% GDP negara tujuan akan meningkatkan ekspor udang tersebut sejalan dengan beberapa penelitian yang dilakukan untuk mengetahui faktor-faktor yang mempengaruhi kinerja ekspor Indonesia antara lain Denantika (2012) yang juga menyatakan bahwa GDP negara tujuan ekspor memiliki pengaruh yang positif dan signifikan terhadap ekspor rumput laut Indonesia ke negara RRT.

Variabel lain yang juga secara signifikan mempengaruhi ekspor udang dan olahan udang lainnya adalah jarak ekonomi antara Indonesia dengan negara tujuan ekspor yang merupakan perbandingan antara jarak geografis kedua negara dan GDP negara tujuan. Koefisien jarak ekonomi memiliki nilai sebesar -0,47 menunjukkan bahwa peningkatan jarak ekonomi sebesar $1 \%$, maka ekspor udang dan udang olahan mengalami penurunan sebesar $0,47 \%$. Tanda yang ditunjukkan oleh variabel koefisien telah sesuai dengan hipotesis berdasarkan teori ekonomi gravity model, yang menyatakan bahwa semakin jauh jarak antara kedua negara, maka intensitas perdagangan antara kedua negarapun semakin berkurang (Tabel 6). 
Tabel 6. Hasil Estimasi Model Gravity

\begin{tabular}{lrr}
\hline \multicolumn{1}{c}{ Variabel } & \multicolumn{1}{c}{ Koef. } & Prob \\
\hline Konstanta ( C) & 0.35 & 0.79 \\
GDP Negara Tujuan (GDP it) & $0.32^{*}$ & 0.07 \\
RER & -0.05 & 0.37 \\
Jarak Ekonomi (DistecoldNit) & $-0.47^{* *}$ & 0.02 \\
Tarif Bea Masuk (BM Bt $_{\text {it }}$ & -0.09 & 0.46 \\
Dummy SPS (SPS & -0.24 & 0.72 \\
Dummy TBT (TBT & -0.36 & 0.62 \\
F-stat & -0.00 & \\
R $^{2}$ & 0.45 & \\
\hline
\end{tabular}

Catatan: ** signifikan pada taraf nyata $5 \%$

* signifikan pada taraf nyata $10 \%$

Variabel nilai tukar riil memiliki koefisien sebesar $-0,05$. Hal tersebut mengindikasikan bahwa apabila nilai tukar rupiah terdepresiasi sebesar $1 \%$ terhadap mata uang negara tujuan, maka ekspor udang dan olahan udang Indonesia justru mengalami penurunan sebesar $0,05 \%$. Tanda yang ditunjukkan oleh variabel tersebut bernilai negatif, berlawanan dengan teori ekonomi yang menyatakan bahwa apabila mata uang semakin terdepresiasi, maka barang akan semakin murah bagi konsumen di luar negeri sehingga ekspor akan bertambah. Variabel nilai tukar riil tidak memiliki pengaruh yang signifikan terhadap ekspor udang dan olahan udang Indonesia yang ditunjukkan dengan nilai $p$-value sebesar $0,37>\alpha$ $=10 \%$. Hal tersebut dapat dijelaskan karena ekspor udang dan olahan udang Indonesa didominasi oleh ekspor udang beku yang termasuk ke dalam industri primer sehingga memiliki sifat tidak elastis terhadap harga.

Tarif bea masuk yang diterapkan negara mitra ternyata memiliki dampak negataif bagi ekspor udang dan olahannya meskipun tidak berpengaruh secara signifikan. Peningkatan tarif bea masuk negara mitra sebesar $1 \%$ akan menurunkan ekspor sebesar 0,09\%. Tanda yang ditunjukkan oleh variabel Bea Masuk juga sesuai dengan hipotesis teori ekonomi dimana peningkatan tarif bea masuk akan menurunkan impor. Secara umum, di sembilan negara tujuan ekspor utama udang Indonesia, tarif bea masuk udang dan udang olahan yang relatif tinggi adalah tarif bea masuk untuk negara-negara yang berada di Eropa yaitu Jerman, Belanda dan Inggris yang masih mengenakan tarif sebesar 10,9\%. Sementara Kanada, RRT dan Malaysia telah mengenakan tarif relatif rendah yaitu $0,0 \%$ sampai dengan 0,5\% di tahun 2015. Sedangkan AS, Vietnam dan Jepang masing-masing memiliki rata-rata tarif bea masuk sebesar $5 \% ; 7,5 \%$ dan 1,65 pada periode yang sama (Tabel 7 ). 
Tabel 7. Rata-rata Tarif Bea Masuk

\begin{tabular}{lrrrrrrrrrrr}
\hline \multirow{2}{*}{ Negara } & \multicolumn{10}{c}{ Tarif Bea Masuk (\%) } \\
\cline { 2 - 13 } & $\mathbf{2 0 0 5}$ & $\mathbf{2 0 0 6}$ & $\mathbf{2 0 0 7}$ & $\mathbf{2 0 0 8}$ & $\mathbf{2 0 0 9}$ & $\mathbf{2 0 1 0}$ & $\mathbf{2 0 1 1}$ & $\mathbf{2 0 1 2}$ & $\mathbf{2 0 1 3}$ & $\mathbf{2 0 1 4}$ & $\mathbf{2 0 1 5}$ \\
\hline Kanada & 0.00 & 0.00 & 0.00 & 0.00 & 0.00 & 0.00 & 0.00 & 0.00 & 0.00 & 0.00 & 0.00 \\
RRT & 5.25 & 3.80 & 4.04 & 4.04 & 3.37 & 6.73 & 3.37 & 0.00 & 0.00 & 0.00 & 0.00 \\
Jerman & 11.11 & 10.90 & 10.90 & 10.90 & 10.90 & 11.68 & 10.90 & 10.90 & 10.90 & 10.90 & 10.90 \\
Jepang & 2.81 & 2.81 & 2.81 & 2.16 & 2.38 & 2.00 & 1.62 & 1.62 & 1.62 & 1.62 & 1.62 \\
Malaysia & 2.00 & 1.79 & 1.51 & 0.40 & 0.50 & 0.67 & 0.50 & 0.50 & 0.50 & 0.50 & 0.50 \\
Belanda & 11.11 & 10.90 & 10.90 & 10.90 & 10.90 & 11.68 & 10.90 & 10.90 & 10.90 & 10.90 & 10.90 \\
Inggris & 11.11 & 10.90 & 10.90 & 10.90 & 10.90 & 11.68 & 10.90 & 10.90 & 10.90 & 10.90 & 10.90 \\
AS & 1.25 & 0.63 & 0.83 & 0.63 & 0.63 & 0.83 & 1.25 & 1.25 & 1.25 & 5.00 & 5.00 \\
Vietnam & 27.00 & 17.50 & 13.00 & 15.00 & 21.00 & 7.50 & 7.50 & 7.50 & 7.50 & 7.50 & 7.50 \\
\hline
\end{tabular}

Sumber: WTO, 2017 (diolah)

Untuk variabel NTMs yaitu SPS dan TBT, hasil analisis menunjukkan bahwa kedua variabel SPS dan TBT memiliki dampak negatif bagi ekspor udang dan olahan udang Indonesia meskipun tidak berpengaruh signikan pada taraf nyata $10 \%$. Instrumen TBT memiliki pengaruh negatif lebih besar untuk mempengaruhi ekspor udang Indonesia di negara tujuan ekspor dibandingkan dengan instrumen SPS yang ditunjukkan dengan nilai koefisien variabel dummy TBT sebesar -0,36. Dalam melakukan interpretasi variabel dummy, terlebih dahulu dilakukan interpretasi ke dalam bentuk natural logaritmanya. Pada Tabel 6 didapatkan nilai konstanta sebesar 0,35 , sehingga anti natural logaritma dari 0,35 adalah 1,42 ribu ton yang menjadi rata-rata nilai ekspor pada pada $\mathrm{D}=0$ atau pada saat tidak terdapat TBT. Sementara pada saat nilai $\mathrm{D}=1$, maka volume ekspornya turun menjadi sebesar 1,0 ribu ton. Nilai tersebut diperoleh dari anti natural logaritma -0.01 yang didapatkan dari penjumlahan koefisien konstanta dan koefisen TBT (0,35 dan 0,36). Dengan demikian, volume ekspor udang ke negara mitra yang menerapkan TBT dapat menurunkan ekspor rata-rata sebesar 0,4 ribu ton atau $30,2 \%$ lebih rendah dibandingkan dengan negara yang tidak terdapat TBT.

Sementara itu, untuk variabel NTMs lainnya yaitu SPS memiliki dampak yang lebih rendah dibandingkan dengan TBT yang ditunjukkan dengan koefisien sebesar -0,24. Dengan menggunakan pendekatan dan metode interpretasi yang sama dengan variabel dummy pada TBT, maka pengenaan SPS dapat menurunkan volume ekspor sebesar 0,3 ribu ton. Dengan demikian, volume 
ekspor udang ke negara mitra yang menerapkan SPS lebih rendah 21,3\% dibandingkan dengan negara yang tidak menerapkan SPS.

KESIMPULAN DAN REKOMENDASI KEBIJAKAN

Udang dan olahan udang menjadi salah satu kontributor utama ekspor dengan pangsa sebesar $43,4 \%$ dari total ekspor ikan dan olahan perikanan. Selama lima tahun terakhir, 2012-2016, ekspor udang memiliki pertumbuhan yang positif sebesar $6,2 \%$ per tahun. Ekspor udang dan olahan udang di tahun 2016 didominasi oleh udang beku dengan pangsa sebesar $78,3 \%$ dari total ekspor udang dan udang olahan. Negara tujuan ekspor udang Indonesia masih terkonsentrasi pada beberapa pasar tertentu, terlihat dari pangsa kumulatif yang ditujukan ke 10 negara tujuan ekspor utama yang mencapai 95,8\%. Amerika Serikat dan Jepang merupakan negara tujuan utama ekspor dengan pangsa masingmasing sebesar $63,0 \%$ dan $20,1 \%$ di tahun 2016.

Berdasarkan hasil analisis dengan menggunakan gravity model dengan menggunakan panel data yang berfokus pada sembilan negara utama tujuan ekspor, variabel yang memberikan pengaruh yang signifikan masing-masing pada taraf nyata $10 \%$ dan 5\% antara lain GDP negara tujuan ekspor dan jarak ekonomi antara Indonesia dengan negara tujuan ekspor. Peningkatan GDP negara tujuan ekspor sebesar $1 \%$ dapat meningkat-kan ekspor udang Indonesia sebesar $\quad 0,32 \%, \quad$ sedangkan penambahan jarak ekonomi sebesar $1 \%$ akan menurunkan ekspor sebesar $0,47 \%$. Bea masuk dan nilai tukar sama-sama memberikan dampak negatif namun tidak secara signifikan berpengaruh.

Hasil analisis juga menunjukkan bahwa NTM memiliki pengaruh negatif terhadap ekspor udang dan olahan udang nasional meskipun tidak berpengaruh secara signifikan. Pengenaan TBT di negara tujuan ekspor memiliki dampak negatif yang lebih besar dibandingkan dengan SPS. Volume ekspor udang dan olahan ke negara mitra yang menerapkan TBT $30,2 \%$ lebih rendah dibandingkan dengan negara yang tidak menerapkan TBT, sementara ekspor ke negara dengan SPS 21,3\% lebih rendah dibandingkan dengan negara yang tidak menerapkan SPS.

Meskipun tidak berpengaruh secara signifikan, namun hasil estimasi menunjukkan bahwa NTM, baik SPS 
dan TBT memiliki pengaruh negatif mengindikasikan bahwa eksportir Indonesia khususnya untuk udang dan olahan udang masih mengalami kesulitan untuk memenuhi standar dan aturan yang diberlakukan di negara tujuan ekspor. Dukungan penuh dari asosiasi pelaku usaha di sektor udang serta perwakilan pemerintah tentu menjadi faktor penting untuk dapat menangani berbagai kasus yang berpotensi menghambat ekspor udang Indonesia. Selain itu, pemerintah perlu berfokus untuk memberikan asistensi bagi para eksportir udang dengan memberikan bantuan informasi pasar serta regulasi yang berlaku dalam rangka memenuhi standar dan persyaratan di negara tujuan ekspor.

UCAPAN TERIMAKASIH

Penulis mengucapkan terima kasih kepada rekan-rekan Pusat Data dan Sistem Informasi Kementerian Perdagangan serta semua pihak yang telah membantu dalam penulisan analisis ini.

\section{DAFTAR PUSTAKA}

Ariyani, N. (2016). Dampak Non Tariff Measures (NTMs) Terhadap Ekspor Rempah-Rempah Indonesia ke Negara Tujuan Ekspor. Skripsi. Bogor: Program Sarjana Institut Pertanian Bogor (IPB).

Bratt, M. (2017). Estimating the bilateral impact of nontariff measures on trade. Review of International

Economics, 25(5), 1105-1129

Badan Pusat Statisik (BPS). (2017a). Pertumbuhan Ekonomi Indonesia Triwulan I-2017.Diunduh tanggal 10 Mei 2017 dari https://www.bps.go.id/index.php/brs/i ndex?Brs page $=2$.

Badan Pusat Statistik (BPS). (2017b). Ekspor Ikan dan Olahan Perikanan Menurut Kelompok Periode 2016 2017 (Januari-Maret).

Badan Pusat Statistik (BPS). (2017c). Ekspor Udang dan Olahan Udang Indonesia Periode $2014 \quad-2017$ (Januari-Maret).

Dahar D. (2014). Analisis Dampak Kebijakan Non Tarif Terhadap Kinerja Ekspor Hortikultura Indonesia ke Negara-Negara ASEAN +3. Tesis. Bogor: Institut Pertanian Bogor.

Denantika, D.P. (2012). Analisis Faktor Faktor yang Mempengaruhi Ekspor Rumput Laut dan Kajian Trend Volume Ekspor Rumput Laut Indonesia ke China. Skripsi, Bogor: Program Sarjana Institut Pertanian Bogor,

Fontagne L., Mimouni M., Pasteels J-M. (2005). Estimating The Impact of Environmental SPS and TBT on Internastional Trade. Geneva: International Trade Center (UNCTAD-WTO).

Fridhowati N. (2013). Dampak Non Tariff Measures (NTM) ASEAN terhadap Arus Perdagangan Sektor Elektronika Indonesia. [Tesis]. Bogor: Institut Pertanian Bogor.

Kahfi, A.S. (2016). Determinants of Indonesia's Exports of Manufactured Products: A Panel Data Analysis. Buletin IImiah Litbang Perdagangan, Vol. 10 (2), pp. 187-201.

Kristriana, O.W. (2015). Analisis Dampak Non Tariff Measures (NTMs) Terhadap Ekspor Tuna Indonesia ke Negara Tujuan Utama. Skripsi. 
Bogor: Program Sarjana Institut Pertanian Bogor (IPB).

Margaretha N. (2012). WTO Convention on Sanitary and Phytosanitary (SPS) Agreement dalam Ekspor Udang Indonesia ke Uni Eropa. [Skripsi]. Bogor: Institut Pertanian Bogor.

Media Indonesia. (2016, Juni 18). Udang Ekspor Kena Infeksi, Pemerintah Tingkatkan Antisipasi. Diunduh tanggal 14 Juli 2017 dari http://www.mediaindonesia.com/news /read/51756/udang-ekspor-kenainfeksi-pemerintah-tingkatkanantisipasi/2016-06-18.

Sari, A. R., Hakim, D. B., \& Anggraeni, L. (2018). Analisis Pengaruh Non-Tariff Measures Ekspor Komoditi Crude Palm Oil (CPO) Indonesia Ke Negara Tujuan Ekspor Utama. Jurnal Ekonomi dan Kebijakan Pembangunan, 3(2).

Shepotylo, O. (2016). Effect of non-tariff measures on extensive and intensive margins of exports in seafood trade. Marine Policy, 68, 47-54.
Sheldon, I., S.K., Mishra., D. Pick \& S.R. Thompson. (2013). Exchange rate uncertainty and US bilateral fresh fruit and fresh vegetable trade: an application of the gravity model. Applied Economics, Vol. 45(15), pp. 2067-2082.

Trademap. (2017). Negara Tujuan Ekspor Udang dan Olahan Udang Indonesia 2016.

UNCTAD. (2012). International Classification of Non Tariff Measures. Geneva: UNCTAD.

UNCTAD. (2013). Non Tariff Measures to Trade: Economic and Policy Issues for Developing Countries. Geneva: UNCTAD.

WTO (2017). Rata-rata Tarif Bea Masuk 2005-2015.

Xiong, B. (2012). Three essays on nontariff measures and the gravity equation approach to trade. Graduate Theses and Dissertations. Iowa State University. 
